\title{
Co-inoculation of rhizobia, azospirilla and cyanobacteria for increasing common bean production
}

\section{Co-inoculação de rizobio, azospirillum e cianobactérias no aumento da produção de feijão comum}

\author{
Eduardo Hélder Horácio ${ }^{1 *}$; Claudemir Zucareli²; Freddy Zambrano Gavilanes ${ }^{3}$; \\ João Sarkis Yunes ${ }^{4}$; Alisson Wilson dos Santos Sanzovo ${ }^{5}$; Diva Souza Andrade ${ }^{6 *}$
}

\section{Highlights:}

Nodulation of common bean is greater with co-inoculation. Co-inoculation of rhizobia, azospirilla and cyanobacteria increase plant growth.

A. cylindrica presents potential as co-inoculant for common bean.

\begin{abstract}
The combined inoculation of Rhizobium ( $R$. tropici+R. freirei), Azospirillum brasilense, and Anabaena cylindrica, a diazotrophic cyanobacterium, is a technology that has not yet been tested and established in the production of the common bean (Phaseolus vulgaris). The inoculation may be a promising strategy for increasing crop productivity by combining the benefits of biological nitrogen fixation with the production of plant growth phytohormones. Therefore, the objective of this study was to evaluate the co-inoculation of Rhizobium, Azospirillum brasilense, and Anabaena cylindrica as an alternative method for optimizing the symbiotic performance and development of the common bean at greenhouse conditions. The treatments were as follows: (T1) control without $\mathrm{N}$ and inoculation, (T2) N addition (100 $\mathrm{kg} \mathrm{N} \mathrm{ha}^{-1}$ ), (T3) Riz (addition of R. tropici + R. freirei), (T4) Azo (Azospirillum brasilense addition), (T5) Ana (Anabaena cylindrical addition), (T6) Riz+Azo, (T7) Riz+Ana, (T8) Azo+Ana, (T9) Riz+Azo+Ana. We used a completely randomized experimental design with four replications. The co-inoculation of $\mathrm{Riz}+\mathrm{Azo}+$ Ana promoted plant height, root length and volume, shoot dry matter, accumulated shoot $\mathrm{N}$, number and dry matter of nodules at flowering, number of grains per pod, hundred seed weight, and grain production of the common bean, contributing to increased yield per plant. We observed an increase in common bean grain yield ranging from 62 to $84 \%$ after double and triple co-inoculation of rhizobia with azospirilla and/or cyanobacteria, with the highest yield observed in the plants inoculated with Riz+Azo+Ana (84\%), similar to those observed in plants after $\mathrm{N}$ addition. However, field experiments are necessary to elucidate the performances of the inoculated beneficial microorganisms.
\end{abstract}

Key words: Anabaena cylindrica. Azospirillum brasilense. Phaseolus vulgaris. Rhizobium freirei. Rhizobium tropici.

\footnotetext{
${ }^{1}$ Prof., Universidade Rovuma, Faculdade de Ciências Alimentares e Agrárias, Nampula, Moçambique. E-mail: ehoracio1986@ gmail.com

2 Prof. Dr., Universidade Estadual de Londrina, UEL, Departamento Agronomia, Londrina, PR, Brasil. E-mail: claudemircca@, uel.br

3 Prof., Universidade Técnica de Manabí, Departamento Agronomia, Portoviejo, Ecuador. E-mail: freddyzg_86@hotmail.com

4 Prof., Universidade Federal do Rio Grande, FURG, Laboratório de Cianobactérias e Ficotoxinas, Instituto de Oceanografia, Rio Grande, RS, Brasil. E-mail: jsyunes@furg.br

5 Discente de Doutorado, Programa de Pós-Graduação em Agronomia, UEL, Londrina, PR, Brasil. E-mail: allissonuenp@gmail.com

6 Pesquisadora, Instituto Agronômico do Paraná, IAPAR, Prof a Programa de Pós-Graduação em Agricultura Conservacionista, IAPAR, Londrina, PR, Brasil. E-mail: diva@iapar.br

* Author for correspondence
} 


\section{Resumo}

A inoculação associada de Rhizobium, Azospirillum e uma cianobactéria diazotrófica Anabaena cylindrica é uma tecnologia que ainda não foi testada e estabelecida para o feijão comum (Phaseolus vulgaris) e pode ser uma estratégia promissora para aumentar a produtividade das culturas, combinando os benefícios da fixação biológica de nitrogênio com a produção de fitohormônios de crescimento vegetal. Portanto, o objetivo deste estudo foi avaliar a co-inoculação de Rizobium, Azospirilum brasilense e Anabaena cylindrica, como uma alternativa para otimizar o desempenho simbiótico e o desenvolvimento do feijoeiro, em casa de vegetação. Os tratamentos foram: T1-control, T2-Nmineral (100 kg N ha $\left.{ }^{-1}\right)$, T3- Rhizobium ( $R$. tropici $+R$. freirei), T4- A. brasilense, T5- A. cylindrica, T6- Rhizobium + A. brasilense, T7- Riz + Ana, T8- Azo + Ana, T9- Riz + Azo + Ana. O delineamento experimental foi inteiramente casualizado, com quatro repetições. A co-inoculação de Rhizobium ( $R$. tropici $+R$. freirei) + Azo + Ana promoveu aumento do feijão (IPR Campos Gerais) em altura das plantas, comprimento e volume de raiz, massa seca da parte aérea, $\mathrm{N}$ acumulado da parte aérea, número e matéria seca dos nódulos no florescimento, número de grãos por vagem, peso de cem grãos e de grãos por planta, o que contribuiu para incremento da produção. Houve um aumento na produção de grãos de feijão com co-inoculação dupla e tripla de rizobia com azospirila e / ou cianobactérias, variando de 62 a $84 \%$, com o maior aumento de produção observado no tratamento inoculado com Riz + Azo + Ana $(84 \%)$, semelhante ao tratamento com nitrogênio mineral. No entanto, experimentos de campo podem contribuir para elucidar o desempenho de microrganismos benéficos inoculados.

Palavras-chave: Anabaena cylindrica. Azospirillum brasilense. Phaseolus vulgaris. Rhizobium freirei. Rhizobium tropici.

\section{Introduction}

Common bean (Phaseolus vulgaris L.) is one of the most commonly grown legume species consumed in many countries because it is an important source of protein. As all legumes, this species has the advantage of performing biological nitrogen fixation when in symbioses with soil bacteria through nitrogenase enzymatic activity.

The symbiotic $\mathrm{N}_{2}$-fixing bacterial strain PRF81 ${ }^{\mathrm{T}}$ isolated from the soil from the south of Paraná state in Brazil, usually referred to as Rhizobium tropici, was reclassified as $R$. freirei (Dall'agnol et al., 2013). This strain PRF81 (=SEMIA4080) is very effective at fixing nitrogen under field conditions and has been successfully used in thousands of doses of commercial inoculants for the common bean combined or not with $R$. tropici strain CIAT899 (=SEMIA4077). The responses of common bean to inoculation with rhizobial strains were reported by Hungria et al. (2000) and by Soares et al. (2016) who combined rhizobia inoculation with $\mathrm{N}$-urea application, which increased crop yield.
Several bacterial species have been studied as possible plant growth-promoting rhizobacteria (PGPR), and the genus Azospirillum, belonging to the group of associative diazotrophic bacteria, is currently one of the most broadly studied and commercially employed PGPRs (Fukami, Cerezini, \& Hungria, 2018). Previous studies on Azospirillum species emphasized their capacity for fixing atmospheric $\mathrm{N}_{2}$ as well as their benefits in promoting plant growth via synthesis of phytohormones. $A$. brasilense promotes plants growth, biological nitrogen fixation, and production of plant hormones, such as auxins, gibberellins, and cytokinins (Fukami, Nogueira, Araujo, \& Hungria, 2016), and it also increases root growth, solubilizes phosphates (Kazi, Deaker, Wilson, Muhammad, \& Trethowan, 2016), and promotes changes in photosynthetic activity of plants (Gordillo-Delgado, Marín, \& Calderón, 2016). Higher productivity was observed with coinoculation of the common bean with $R$. tropici on the seeds and $A$. brasilense applied in the planting furrow (Hungria, Nogueira, \& Araujo, 2013). 
Few studies investigated the co-inoculation of cyanobacteria, for example, Anabaena cylindrica, Calothrix brevíssima, and Nostoc muscorum with other $\mathrm{N}$-fixing bacteria, such as those of the genus Rhizobium in legumes. In agricultural practices, cyanobacteria demonstrated the potential to be used as fertilizers, for their production of substances that stimulate plant growth, or even for increasing biological nitrogen fixation (BNF) in wheat (Jaiswal, Prasanna, Nayak, Sood, \& Suseela, 2008) or bioavailability of soil nutrients and yield of okra (Manjunatha et al., 2016).

The species Anabaena cylindrica is a diazotrophic cyanobacterium which produces pigments, biofertilizers, and polysaccharides, and possesses specialized nitrogen-fixing cells called heterocysts (Loreto, Rosales, Bermúdez, \& Morales, 2003). In addition to contributing to BNF, A. cylindrica is able to increase iron solubility by producing siderophores (Wirtz, Treble, \& Weger, 2010). Foliar application of the cyanobacterium Anabaena (PCC 7120) and bio-stimulators was found to partly alleviate the harmful impacts of adverse temperature and water stress on growth and physiological activity of willow (Salix viminalis) plants (Piotrowska-Niczyporuk, Bajguz, Kotowska, Bralska, \& Talarek-Karwel, 2018). Ghaderiardakani, Collas, Damiano, Tagg, \& Graham, (2019) found that the use of algal extracts from Ulva intestinalis as fertilizers should be cautious as its inhibitory effects during plant early development may outweigh any benefits if the concentration of the algal extract is too high.

Combination of multiple inoculants has a higher success rate than the use of a single inoculant, and it can significantly improve plant nutrition by increasing the adsorption of nitrogen, phosphorus, and other mineral nutrients, thereby promoting plant growth and increasing the yield. The aim of this study was to determine the effect of co-inoculation of rhizobia ( $R$. tropici $+R$. freirei), A. brasilense, and A. cylindrica on the growth, nodulation, and yield of the common bean grown in pots in order to provide information about the potential of A. cylindrica as inoculant. We hypothesized that the investigated characteristics of the common bean would be greater when the plants are co-inoculated with of rhizobia, azospirilla, and cyanobacteria than when the plants are inoculated with only one or two microorganisms, and therefore, we put emphasis on studying the combinations of two PGPRs, $A$. brasilense and $A$. cylindrica, with the rhizobia strains recommended for Phaseolus vulgaris by Ministry of Agriculture, Livestock and Food Supply of Brazil.

\section{Materials and Methods}

\section{Experimental design}

The experiment was carried out in a greenhouse $\left(23^{\circ} 23^{\prime} \mathrm{S}\right.$ and $51^{\circ} 11^{\prime} \mathrm{W}$, and at an altitude of 566 m) with controlled temperature of $27 \pm 3{ }^{\circ} \mathrm{C}$ and relative air humidity of $80 \pm 5 \%$ from February to April 2018. The treatments were as follows: T1, control without $\mathrm{N}$ and inoculation, $\mathrm{T} 2, \mathrm{~N}$ addition (100 kg N ha-1), T3, Riz (R. tropici $+R$. freirei), T4, Azo (Azospirillum brasilense), T5, Ana (Anabaena cylindrica), T6, Riz+Azo, T7, Riz+Ana, T8, Azo+Ana, T9, Riz+Azo+Ana. The experiment was conducted in a completely randomized experimental design with four replications.

The substrate was composed of a mixture (1:2, $\mathrm{v} / \mathrm{v}$ ) of washed sand with clayey soil, from $0-0.20$ $\mathrm{m}$ depth layer, with granulometry of 760 clay, 150 sand, and 90 sand $\left(\mathrm{g} \mathrm{kg}^{-1}\right)$, which is classified as Haplustox according to Soil Survey Staff (2014). The soil was sieved to remove pebbles and organic material, and fertilizers were applied based on the recommendations for the common bean and according to the results of the chemical analysis (Parra \& Oliveira, 2003). The volume of $8 \mathrm{dm}^{3}$ of soil was added to each plastic pot. All treatments received phosphorous and potassium in the ratio of $30: 10$, equivalent to $60 \mathrm{~kg} \mathrm{ha}^{-1}$ of $\mathrm{P}_{2} \mathrm{O}_{5}$ and $60 \mathrm{~kg} \mathrm{ha}^{-1}$ of $\mathrm{K}_{2} \mathrm{O}$. Nitrogen $\left(100 \mathrm{~kg} \mathrm{~N}^{-1}\right)$, which was added in the form of urea, was applied at sowing (30 kg ha$\left.{ }^{1}\right)$ and 20 days after germination in topdressing (70 
$\left.\mathrm{kg} \mathrm{ha}^{-1}\right)$. Before sowing, subsamples were collected for chemical analysis which showed the following: $\mathrm{pH}\left(\mathrm{CaCl}_{2} 0,01 \mathrm{~mol} \mathrm{~L}^{-1}\right) 5.7,13.1 \mathrm{~g} \mathrm{~kg}^{-1}$ of organic matter, $27.2 \mathrm{mg} \mathrm{dm}^{-3}$ of P, $0.64 \mathrm{cmol}_{\mathrm{c}} \mathrm{dm}^{-3}$ of $\mathrm{K}^{+}, 6.0$ $\mathrm{cmol}_{\mathrm{c}} \mathrm{dm}^{-3}$ of $\mathrm{Ca}^{2+}, 2.2 \mathrm{cmol}_{\mathrm{c}} \mathrm{dm}^{-3}$ of $\mathrm{Mg}^{2+}$, and 13.45 $\mathrm{cmol}_{\mathrm{c}} \mathrm{dm}^{-3}$ of cation exchange capacity at $\mathrm{pH}$ 7.0.

\section{Seeding and inoculation}

Before sowing, the seeds were inoculated with liquid inoculants according to the corresponding treatments. For the inoculants with rhizobia and azospirilla, we used the doses recommended by the manufacturer (100 mL per $25 \mathrm{~kg}$ of seeds), with the concentration of $1.0 \times 10^{9}$ viable cells $\mathrm{mL}^{-1}$ of $R$. freirei (SEMIA4080=PRF81) and $R$. tropici (SEMIA4077=CIAT899) and a minimum concentration of $2.0 \times 10^{8}$ viable cells $\mathrm{mL}^{-1}$ of $A$. brasilense (AbV5 and AbV6). For A. cylindrica, we used the dose of $5 \mathrm{~mL}$ per $1 \mathrm{~kg}$ of seeds containing on average $1.0 \times 10^{8}$ viable cells $\mathrm{mL}^{-1}$.

The seeding was carried out on February $5^{\text {th }}$, 2018. We used the seeds of IPR Campos Gerais, a cultivar belonging to the Carioca group with indeterminate growth, flowering of 43 days, cycle of 92 days, and average of $22 \%$ of grain protein content. Five seeds per pot were distributed at the depth of $2 \mathrm{~cm}$.

The inoculants were applied to the seeds in the shade, and the seeds were allowed to air dry for a few minutes before sowing. Then, the seeds were immediately covered with soil in order to avoid desiccation. After germination, the seedlings were thinned, leaving three plants per pot. During the experiment, soil moisture was kept at approximately $60 \%$ to $70 \%$ of water hold capacity by daily irrigation with distilled water. Weeds were removed manually from the pots.

\section{Plant growth, nodulation, and productivity}

During flowering, three plants per pot were collected and taken to the laboratory for the determination of plant height, root length and volume, number of nodules, nodule dry weight, shoot dry weight, and accumulated shoot nitrogen.

The plant height $(\mathrm{cm})$ was determined from the soil surface to the tip of the apical meristem with the aid of a ruler. Root volume $(\mathrm{mL})$ was determined by measuring the displacement of the water column in a graduated cylinder: after washing and drying the roots, we placed them in a graduated cylinder containing a known volume of water (100 $\mathrm{mL}$ ). From the difference, we determined the root volume. The roots were separated from the shoots at the base of the stem and the root length $(\mathrm{cm})$ was measured using a graduated plastic ruler.

After the evaluation of root length and volume, the roots were washed with running water using sieves, and the number of nodules was counted. Nodule dry matter was determined after air-drying the nodules in a circulating oven at $65{ }^{\circ} \mathrm{C}$ for $72 \mathrm{~h}$ until they reached constant weight. The data were transformed into number of nodules per plant and dry matter of nodules per plant (mg).

Shoot dry matter (g) was determined after an airdrying the shoots in a circulation oven at $65{ }^{\circ} \mathrm{C}$ for $72 \mathrm{~h}$ until they reached constant weight. Shoot dry matter samples were ground in a laboratory mill and $\mathrm{N}$ content was determined according to the Kjeldahl digestion method (Bremner \& Keeney, 1965). The amount of accumulated $\mathrm{N}$ was calculated from the $\mathrm{N}$ content and shoots dry weight by using the following equation:

$$
\mathrm{ASN}=\left(\mathrm{SDM}^{*} \mathrm{~N}_{\mathrm{det}}\right) / 1000
$$

Where:

$\mathrm{ASN}=$ accumulated shoot nitrogen in $\mathrm{mg}_{\text {plant }}{ }^{-1}$.

$\mathrm{SDM}=$ shoot dry matter in $\mathrm{g}$ per plant of each treatment.

$\mathrm{N}_{\text {det }}=$ nitrogen content expressed in $\mathrm{g} \mathrm{N}$ per $1000 \mathrm{~g}$ of SDM of each treatment. 
After 90 days of seeding, the plants were harvested in order to evaluate pod number per plant, number of seeds per pod, weight of hundred seeds, and grain production per plant.

\section{Statistical analysis}

The data were submitted to analysis of variance and the means were compared with the Scott-Knott test $(p<0.05)$ using the statistical software SISVAR (Ferreira, 2011). Principal component analysis (PCA), and heat-maps were generated using the software R (R Core Team, 2018, www.r-project.org).

\section{Results}

\section{Plant nodulation}

The treatments containing Rhizobium ( $R$. tropici $+R$. freirei), regardless of inoculation or coinoculation with $A$. brasilense and A. cylindrical, increased the number of nodules and nodule dry matter compared to the treatments without rhizobia (Table 1).

Table 1

Effects of inoculation with rhizobia, azospirilla, and cyanobacteria on plant height (PH), root length (RL), root volume (RV), number of nodules (NN), nodule dry matter (NDM), of the common bean (IPR Campos Gerais)

\begin{tabular}{lccccc}
\hline Treatment & $\mathrm{PH}$ & $\mathrm{RL}$ & $\mathrm{RV}$ & $\mathrm{NN}$ & $\mathrm{NDM}$ \\
\hline & $\mathrm{cm}$ & $\mathrm{cm}$ & $\mathrm{mL}$ & $\mathrm{n}^{\mathrm{o}}$ & $\mathrm{mg} \mathrm{pl}^{-1}$ \\
\hline $\mathrm{T} 1$ & $33.5 \mathrm{~b}$ & $23.1 \mathrm{~b}$ & $17.5 \mathrm{~b}$ & $32.8 \mathrm{~b}$ & $27.9 \mathrm{~b}$ \\
$\mathrm{~T} 2$ & $55.0 \mathrm{a}$ & $33.3 \mathrm{a}$ & $31.4 \mathrm{a}$ & $35.3 \mathrm{~b}$ & $28.6 \mathrm{~b}$ \\
$\mathrm{~T} 3$ & $52.8 \mathrm{a}$ & $28.8 \mathrm{a}$ & $30.4 \mathrm{a}$ & $132.8 \mathrm{a}$ & $129.4 \mathrm{a}$ \\
$\mathrm{T} 4$ & $58.8 \mathrm{a}$ & $32.5 \mathrm{a}$ & $34.4 \mathrm{a}$ & $45.0 \mathrm{~b}$ & $31.1 \mathrm{~b}$ \\
T5 & $54.3 \mathrm{a}$ & $29.3 \mathrm{a}$ & $28.8 \mathrm{a}$ & $33.8 \mathrm{~b}$ & $29.6 \mathrm{~b}$ \\
T6 & $54.0 \mathrm{a}$ & $30.5 \mathrm{a}$ & $27.5 \mathrm{a}$ & $113.8 \mathrm{a}$ & $110.2 \mathrm{a}$ \\
T7 & $54.8 \mathrm{a}$ & $33.8 \mathrm{a}$ & $28.3 \mathrm{a}$ & $122.5 \mathrm{a}$ & $145.6 \mathrm{a}$ \\
T8 & $56.5 \mathrm{a}$ & $30.3 \mathrm{a}$ & $31.1 \mathrm{a}$ & $40.5 \mathrm{~b}$ & $33.2 \mathrm{~b}$ \\
T9 & $60.8 \mathrm{a}$ & $33.5 \mathrm{a}$ & $33.4 \mathrm{a}$ & $128.8 \mathrm{a}$ & $154.4 \mathrm{a}$ \\
\hline Mean Square Value & $247.06^{*}$ & $45.3 *$ & $99.63^{*}$ & $8563.9^{*}$ & $1279.03^{*}$ \\
Residue & 63.09 & 12.1 & 26 & 837.8 & 1021.8 \\
\hline CV (\%) & 14.9 & 11.4 & 17.5 & 38.03 & 41.7 \\
\hline
\end{tabular}

$\mathrm{T} 1$, control without $\mathrm{N}$ and inoculation, $\mathrm{T} 2, \mathrm{~N}$ addition $\left(100 \mathrm{~kg} \mathrm{~N} \mathrm{ha}^{-1}\right), \mathrm{T} 3$, Riz (R. tropici + R. freirei), T4, Azo (Azospirillum brasilense), T5, Ana (Anabaena cylindrica), T6, Riz+Azo, T7, Riz+Ana, T8, Azo+Ana, T9, Riz+Azo+Ana. * marks significance at $5 \%$ in the $\mathrm{F}$ test. The displayed values are means of four repetitions, and when followed by the same letter within same column, they were not significantly different (Skott-Knott test, $\mathrm{p}<0.05$ ). $\mathrm{CV}=$ coefficient of variation.

\section{Plant growth and productivity}

In the plants under the treatments with $\mathrm{N}$ and under all treatments with the inoculation of rhizobia ( $R$. tropici $+R$. freirei), A. brasilense, and
A. cylindrica and co-inoculations of Rhizobium + A. brasilense, Riz+Ana, Azo+Ana, and Riz+Azo+Ana, plant height, root length, and root volume increased significantly $(p<0.05)$ compared to those in the control plants (Table 1). 
We observed an increase in shoot dry matter, accumulated shoot nitrogen, and number of grains per pod in plants after the inoculation and co-inoculation with the three microorganisms compared to those in the uninoculated plants. The number of pods per plant was not affected by the treatments (Table 2).

\section{Table 2}

Effects of inoculation with rhizobia, azospirilla, and cyanobacteria on shoot dry matter (SDM), accumulated shoot nitrogen (ASN), number of pods per plant (NPP), number of grains per pod (NGP), hundred grain weight (HGW), grain plant weight (GPW), and grain production increase per plant (GPI) of the common bean (IPR Campos Gerais)

\begin{tabular}{lccccccc}
\hline Treatment & SDM & ASN & NPP & NGP & HGW & GPW & GPI \\
\hline & $\mathrm{g} \mathrm{pl}^{-1}$ & $\mathrm{mg} \mathrm{pl}^{-1}$ & & No & $\mathrm{g}$ & $\mathrm{g} \mathrm{pl}^{-1}$ & $\%$ \\
$\mathrm{~T} 1$ & $9.1 \mathrm{~b}$ & $138.1 \mathrm{~b}$ & 7.0 & $4.6 \mathrm{~b}$ & $27.4 \mathrm{~b}$ & $6.1 \mathrm{c}$ & - \\
$\mathrm{T} 2$ & $10.8 \mathrm{a}$ & $316.8 \mathrm{a}$ & 9.5 & $6.6 \mathrm{a}$ & $31.2 \mathrm{a}$ & $11.0 \mathrm{a}$ & $86.3 \mathrm{a}$ \\
$\mathrm{T} 3$ & $11.3 \mathrm{a}$ & $317.3 \mathrm{a}$ & 9.0 & $6.4 \mathrm{a}$ & $32.1 \mathrm{a}$ & $10.0 \mathrm{a}$ & $77.5 \mathrm{a}$ \\
$\mathrm{T} 4$ & $11.1 \mathrm{a}$ & $243.2 \mathrm{a}$ & 8.5 & $5.8 \mathrm{a}$ & $27.5 \mathrm{~b}$ & $8.1 \mathrm{~b}$ & $33.7 \mathrm{~b}$ \\
$\mathrm{~T} 5$ & $10.7 \mathrm{a}$ & $274.4 \mathrm{a}$ & 9.0 & $5.8 \mathrm{a}$ & $24.8 \mathrm{~b}$ & $8.5 \mathrm{~b}$ & $41.9 \mathrm{~b}$ \\
$\mathrm{~T} 6$ & $11.2 \mathrm{a}$ & $227.2 \mathrm{a}$ & 9.2 & $6.2 \mathrm{a}$ & $31.1 \mathrm{a}$ & $9.8 \mathrm{a}$ & $63.6 \mathrm{a}$ \\
$\mathrm{T} 7$ & $11.0 \mathrm{a}$ & $259.0 \mathrm{a}$ & 9.3 & $6.2 \mathrm{a}$ & $31.4 \mathrm{a}$ & $9.7 \mathrm{a}$ & $62.4 \mathrm{a}$ \\
T8 & $10.7 \mathrm{a}$ & $238.2 \mathrm{a}$ & 9.1 & $6.2 \mathrm{a}$ & $30.8 \mathrm{a}$ & $8.7 \mathrm{~b}$ & $43.1 \mathrm{~b}$ \\
T9 & $12.2 \mathrm{a}$ & $321.3 \mathrm{a}$ & 9.3 & $6.7 \mathrm{a}$ & $32.3 \mathrm{a}$ & $11.1 \mathrm{a}$ & $84.4 \mathrm{a}$ \\
\hline Mean square value & $2.69^{*}$ & $3569.7^{*}$ & $2.3^{\text {ns }}$ & $1.64^{*}$ & $27.0^{*}$ & $11.2^{*}$ & $3133.5^{*}$ \\
Residue & 0.82 & 3430.5 & 2.31 & 0.48 & 10.4 & 0.9 & 744.1 \\
\hline CV (\%) & 8.3 & 22.6 & 17.1 & 11.4 & 10.8 & 10.4 & 49.8 \\
\hline
\end{tabular}

$\mathrm{T} 1$, control without $\mathrm{N}$ and inoculation, $\mathrm{T} 2, \mathrm{~N}$ addition $\left(100 \mathrm{~kg} \mathrm{~N} \mathrm{ha}^{-1}\right), \mathrm{T} 3, \mathrm{Riz}$ (R. tropici+R. freirei), T4, Azo (Azospirillum brasilense), T5, Ana (Anabaena cylindrica), T6, Riz+Azo, T7, Riz +Ana, T8, Azo+Ana, T9, Riz+Azo+Ana. * marks significance at $5 \%$ in the $\mathrm{F}$ test. The displayed values are means of four repetitions, and when followed by the same letter within same column, they were not significantly different (Skott-Knott test, $\mathrm{p}<0.05$ ). $\mathrm{CV}=$ coefficient of variation.

Higher hundred grain weights were observed in plants after the inoculation of rhizobia ( $R$. tropici $+R$. freirei), co-inoculation of $\mathrm{Riz}+\mathrm{Azo}, \mathrm{Riz}+\mathrm{Ana}$, Azo + Ana, $\mathrm{Riz}+\mathrm{Azo}+\mathrm{Ana}$, and $\mathrm{N}$ treatments compared to those in the other treatments (Table 2).

\section{Principal components analysis and heatmaps}

The PCA showed that the variables formed a two-dimensional plane, which was explained by $\operatorname{Dim} 1$ (71\%) and Dim2 (17\%), corresponding to the sum of $88 \%$ of the total data variation (Figure 1). 


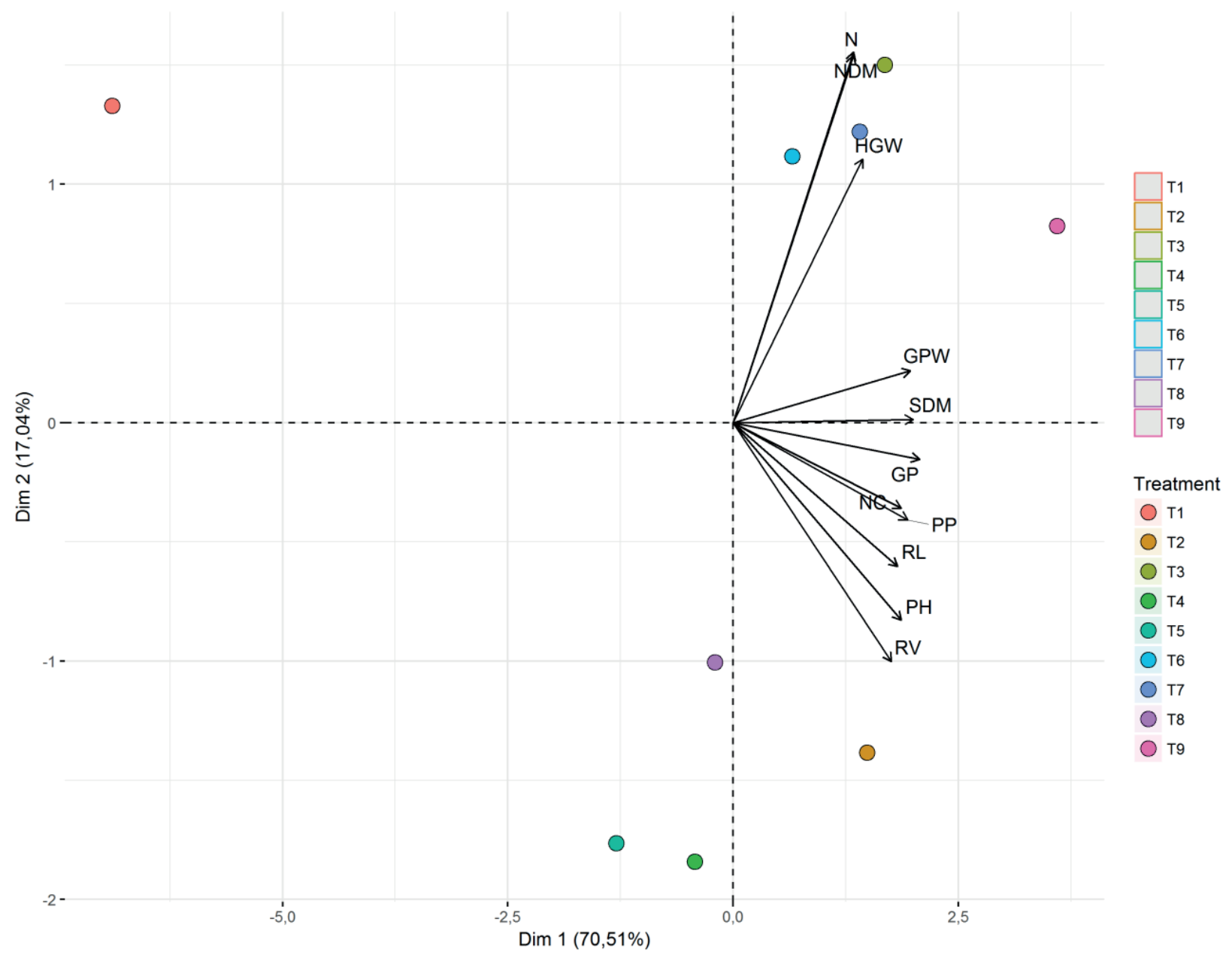

Figure 1. Principal component analysis of the dependent and independent variables evaluated in the common bean (IPR Campos Gerais).

Independent variables: $\mathrm{T} 1$, control without $\mathrm{N}$ and inoculation, $\mathrm{T} 2, \mathrm{~N}$ addition $\left(100 \mathrm{~kg} \mathrm{~N}^{-1}\right), \mathrm{T} 3$, Riz $(R$. tropici $+R$. freirei), T4, Azo (Azospirillum brasilense), T5, Ana (Anabaena cylindrica), T6, Riz+Azo, T7, Riz+Ana, T8, Azo+Ana, T9, Riz+Azo+Ana. Dependent variables: RV, root volume, PH, plant height, SDM, shoot dry matter, NPP, number of pods per plant, RL, root length, GPW, grain plants weight, NGP, number of grains per pod, ASN, accumulated shoot nitrogen, NN, number of nodules, NDM, nodule dry matter, HGW, hundred grain weight.

The results of the clustering analysis (heatmaps) showed that the nine treatments and the 12 variables were both divided into three groups (Figure 2):
(1) the control treatment; (2) inoculation and coinoculation with $A$. brasilense and A. cylindrica, and (3) the other treatments. 


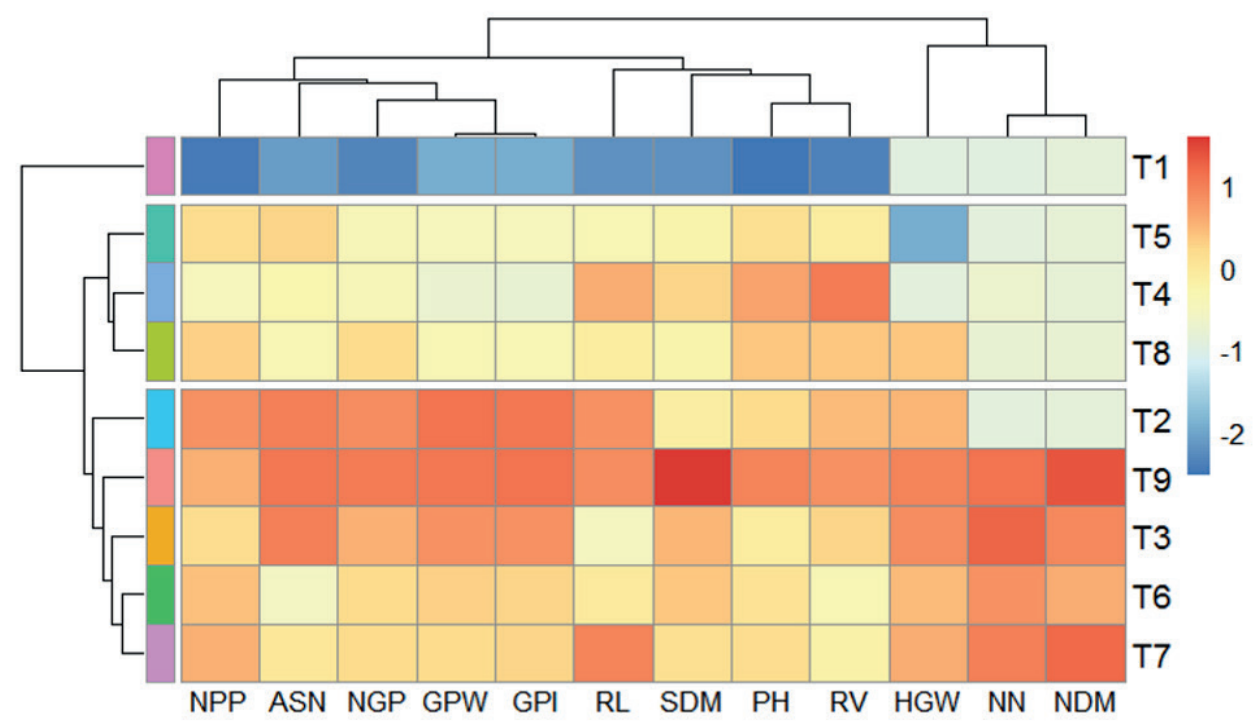

Figure 2. Clustering analysis (heatmap) based on the dependent (x-axis dendrogram) and independent variables (y-axis dendrogram) evaluated in common bean (cultivar IPR Campos Gerais).

Independent variables: $\mathrm{T} 1$, control without $\mathrm{N}$ and inoculation, $\mathrm{T} 2, \mathrm{~N}$ addition (100 $\mathrm{kg} \mathrm{N} \mathrm{ha-1),} \mathrm{T3,} \mathrm{Riz} \mathrm{(R.} \mathrm{tropici}+R$. freirei), T4, Azo (Azospirillum brasilense), T5, Ana (Anabaena cylindrica), T6, Riz+Azo, T7, Riz+Ana, T8, Azo+Ana, T9, Riz+Azo+Ana. Dependent variables: $\mathrm{RV}$, root volume, $\mathrm{PH}$, plant height, SDM, shoot dry matter, NPP, number of pods per plant, RL, root length, GPI, increase of grain production per plant, GPW, grain plants weight, NGP, number of grain per pod, ASN, accumulated shoot nitrogen, NN, number of nodules, NDM, nodule dry matter, HGW, hundred grain weight. The scale of the color bars ranges from -2 (blue, lowest similarity) to 1 (red, highest similarity).

\section{Discussion}

\section{Effects of co-inoculation on plant development and nodulation}

Plant height, root volume and length, shoot dry mass, accumulated shoot nitrogen, and number of grains per pod of plants in all treatments were higher than those of the control. Single inoculation with Rhizobium and co-inoculation with $A$. brasilense and A. cylindrica resulted in higher number and mass of nodules than those in the control treatments, after $\mathrm{N}$ addition, and after inoculation with Azo, Ana, and co-inoculation of Azo+Ana. These results proved that the inoculated strains are more efficient than soil bacteria in providing $\mathrm{N}$ to the common bean plants. One study found that in the pots with sandy soil, common bean plants (IPR Colibri) inoculated with these same rhizobial strains as the ones used in the present study (CIAT899 and PRF81) exhibited an average of $334 \mathrm{mg}^{\text {plant }}{ }^{-1}$ of dry mass of nodules (Cardoso, Hungria, \& Andrade, 2012). Co-inoculation of Rhizobium and Azospirillum increased the nodulation of the common bean plants in the second year of cultivation, but, in an average of two years, no differences were observed between the yields of $2250 \mathrm{~kg} \mathrm{ha}^{-1}$ for control and $2166 \mathrm{~kg}$ $\mathrm{ha}^{-1}$ for co-inoculated treatment (Peres, Rodrigues, Arf, Portugal, \& Corsini, 2016).

\section{Plant productivity}

Shoot dry matter can be correlated with plant growth, i.e., higher shoot dry matter is correlated with greater number of leaves and leaf area, root 
thickening, and root growth, in turn increasing the photosynthetic activity and the exploitation of nutrients from the soil, contributing to the productive performance of plants.

Application of PGPR may result in size inequality within the crop yield, even if there are no absolute changes in plant yield. These results have important implications for consumers as well as for farmers, growers, and producers of microbial inoculants. It has been suggested that in future studies of organic systems, an analysis of size inequality should accompany experiments involving PGPR because these products need to be more made-to-order to specific crop situations or soil types, and a universal inoculant is therefore unlikely to be developed at present (Gange \& Gadhave, 2018).

In the present study, we observed a synergism between PGPR and nitrogen-fixing leguminous bacteria. Studies have showed that the production of indole-3-acetic acid and/or cellulase by Pseudomonas strains may contribute to this effect (Egamberdieva, Berg, Lindström, \& Räsänen, 2010). Co-inoculation of Bradyrhizobium sp. and Paenibacillus durus to cowpea was found to have a positive effect on plant height, shoot dry matter, root length and root dry matter, and accumulated shoot $\mathrm{N}$ at all evaluated times (Rodrigues, Antunes, Medeiros, Barros, \& Figueiredo, 2012). A significant positive effect of co-inoculation with Pseudomonas sp. and R. phaseoli on the growth, $\mathrm{N}$, and $\mathrm{P}$ contents of common bean plants compared to those of the plants inoculated only with Rhizobium has also been observed (Stajković et al., 2011).

Beneficial effects of rhizobia on the common bean have been described in several studies with different climatic and soil conditions (Mulas, Seco, Casquero, Velázquez, \& González-Andrés, 2015; Soares et al., 2016). In a study that evaluated the effects of $\mathrm{N}$ fertilization and inoculation with $R$. freirei (SEMIA 4081=PRF81) on the nodules and yield of common bean grains, Yagi, Andrade, Waureck and Gomes (2015) found that regardless of nodulation with native or inoculated rhizobia, cultivars of Carioca group were more efficient in biological $\mathrm{N}$ fixation and more productive than cultivars of the control group.

It is important to highlight that the plants that were not inoculated with Rhizobium also developed nodules, indicating the presence of native nitrogenfixing bacteria in the soil. When bacteria of the genus Rhizobium are introduced via inoculants, the possibility of native bacteria species in the soil does not exclude nodulation unless inoculation is performed to sterilized soil.

The effects of treatments on the number of grains per pods were found to be statistically significant. Inoculation of rhizobia ( $R$. tropici $+R$. freirei), $A$. brasilense, and A. cylindrica, and co-inoculation of rhizobia with $A$. brasilense, rhizobia with $A$. cylindrica, Azo+Ana, and Riz+Azo+Ana, and $\mathrm{N}$ addition treatment resulted in plants with the highest number of grains per pod, whereas the control plants had the lowest number of grains per pod.

The positive effect of the inoculation with $A$. cylindrica on plant growth and development in our study can be attributed to improved nutrient uptake, production of growth regulators, activation of photosynthesis, better supply of macro- and micronutrients to plants, and decreased number of floral abortions (Ghaderiardakani et al., 2019; Tate, Gutierrez-Wing, Rusch, \& Benton 2013). In plants inoculated with $A$. brasilense, this positive effect can also be attributed to the symbiotic capacity of legumes, production of growth hormones, and the ability to perform biological nitrogen fixation (Bashan, Bashan, Prabhu, \& Hernandez, 2014).

Regarding to grain yields, similar to the $\mathrm{N}$ addition treatment, the treatments with co-inoculation of rhizobia, azospirilla, and cyanobacteria presented significantly higher results, whereas plants from the treatment without Rhizobium (A. brasilense $+A$ cylindrica) had intermediate productivity, showing the essential role of $\mathrm{N}_{2}$-fixing bacteria in the growth and development of the common bean. 
Grain production per plant in plants inoculated with rhizobia ( $R$. tropici $+R$. freirei), co-inoculated with Riz+Azo, Riz+Ana, Riz+Azo+Ana, and fertilized with $\mathrm{N}$ was $77.5,63.6,62.4,84.4$, and $86,3 \%$ higher than that of the control, indicating that nitrogen fertilization can be replaced by inoculation with selected strains of rhizobia ( $R$. tropici $+R$. freirei) and by co-inoculation with $A$. brasilense and $A$. cylindrica. Inoculation and co-inoculation of $A$. cylindrica and $A$. brasilense without rhizobia showed no significant gains compared to control. These results are in agreement with those reported by Steiner, Ferreira and Zuffo (2019) who found that the grain yield was significantly greater when common bean seeds were inoculated with $R$. tropici alone and combined with $A$. brasilense (co-inoculation), whereas it was lower in noninoculated plants and in plants inoculated only with A. brasilense.

A significant increase in the production and productivity traits of the common bean after the co-inoculation of Rhizobium phaseoli with Pseudomonas fluorescens P-93 and A. lipoferum S-21 was observed (Yadegari, 2014). Regardless of the variations in their results, Schossler, Meert, Rizzardi and Michalovicz (2016) stated that the association of different bacteria with different functions, mainly growth-promoting and nitrogenfixing bacteria, contributed to the growth, development, and productivity of the common bean, which was also observed in the present study. These authors also observed that the highest thousand grain weight and yield productivity of common bean were achieved after inoculation of plants with $R$. tropici and co-inoculation with $A$. brasilense. Co-inoculation of rhizobia with nodule endophytic PGPR was found to enhance the growth of the common bean in phosphorous-deficient soil under greenhouse conditions (Korir, Mungai, Thuita, Hamba, \& Masso, 2017). In one study under field conditions, for three growing seasons, an increase of $8.3 \%$ in plant productivity was observed when common bean seeds were inoculated with $R$. tropici, and an increase of $19.6 \%$ was observed when the seeds were co-inoculated with $R$. tropici and $A$. brasilense (Hungria et al., 2013).

The use of cyanobacteria as a biofertilizer is a well-known practice in crops, mainly in rice cultivation (Renuka, Guldhe, Prasanna, Singh, \& Bux, 2018). Therefore, research involving the inoculation of cyanobacteria in legumes is promising and there are results showed positive effects of this inoculation, which are mainly when associated with plant growth-promoting and nitrogen-fixing bacteria. Andrade, Machineski, Lovato, Colozzi and Goes (2014) reported that the co-inoculation of cyanobacteria strains (IPR-7061 and IPR-7059) with of $R$. tropici (SEMIA 4077=CIAT899) to common bean, with of Bradyrhizobium japonicum (SEMIA 5079) to soybean (Glycine max (L.) Merril), or with of Bradyrhizobium sp. (SEMIA 6144) to groundnut (Arachis hypogaea) increased the number of nodules, nodule weight, and grain production in plants in field experiments.

\section{$P C A$ and heatmaps}

In the PCA, the treatments of microbial inoculation without rhizobia were isolated on the left side of the biplot, showing no relation to any of the studied variables. The number of nodules, nodule dry matter, hundred grain weight, shoot dry matter, and grain plant weight showed high correlation with all four microorganism inoculation treatments: i) single inoculation of rhizobia inoculant (R. tropici+freirei); ii) co-inoculation of rhizobia with azospirilla, iii) co-inoculation of rhizobia (R. tropici+R. freirei) with cyanobacteria, and iv) tripartite co-inoculation (rhizobia, azospirilla, and cyanobacteria).

The $\mathrm{N}$ fertilization treatment had a high correlation with accumulated shoot $\mathrm{N}$, root volume, root length, number of grains per pod, number of pods per plant, and plant height.

The PCA showed that the variables analyzed formed a two-dimensional plane with $87.5 \%$ of the 
variability of the original data, which is according to Rencher (2002) reported that the sum of the first two components of the PCA must be greater than $70 \%$ of the total variation of the data.

The treatments in which seeds were inoculated with beneficial microorganisms were grouped together and had higher values of root volume, plant height, shoot dry matter, number of pods per plant, root length, grain production, grain weight per plant, number of grains per plant, and accumulated shoot $\mathrm{N}$ than those of the control and those of the $\mathrm{N}$ fertilization treatment. In addition, plants inoculated with rhizobia ( $R$. tropici $+R$. freirei), Riz+Azo, Riz+Ana, and $\mathrm{Riz}+\mathrm{Azo}+\mathrm{Ana}$ also had high values of nodule dry matter, number of nodules, and weight of hundred grains. N fertilization and $\mathrm{Azo}+$ Ana treatments also resulted in high weight of hundred grains, whereas the opposite was observed in the control treatment. The heatmap analysis showed three groups: the first one comprised the control treatment; the second one comprised the treatments with $A$. brasilense, A. cylindrica, and $A$. brasilense $+A$. cylindrica, and the third one comprised the $\mathrm{N}$ fertilization, Riz, $\mathrm{Riz}+\mathrm{Azo}, \mathrm{Riz}+\mathrm{Ana}$, and $\mathrm{Riz}+\mathrm{Azo}+\mathrm{Ana}$ treatments.

The cluster analysis (heatmap) showed a similar result to the PCA for the analyzed variables, the control treatment being the most separate from the others, while the treatment with co-inoculation of $\mathrm{Riz}+\mathrm{Azo}+$ Ana was the one that presented high values for all characteristics evaluated, corroborating with the results observed in univariate statistical analysis.

The co-inoculation of rhizobia ( $R$. tropici $+R$. freirei) with $A$. brasilense and $A$. cylindrica resulted in an increase in plant height, root length, root volume, shoot dry matter, accumulated shoot $\mathrm{N}$, number of nodules, nodule dry matter, number of grains per pods, hundred grain weight, and grain production per plant, with increases similar to those in plants under the $\mathrm{N}$ fertilization treatment. The species A. cylindrica demonstrated the potential to be used as biofertilizer in the production of the common bean, mainly in co-inoculation with rhizobia ( $R$. tropici $+R$. freirei) and A. brasilense. However, field experiments are still needed to elucidate the performance of microorganisms in these processes.

\section{Conclusion}

We found that the co-inoculation of rhizobia, azospirilla, and cyanobacteria increased nodulation, plant growth, and production of the common bean. When the common bean is cultivated in soils with lower nitrogen content, rhizobial inoculation with selected strains is the recommended agricultural practice because it is essential for supplying the common bean with enough N. Our results provide new information on the usage of $A$. cylindrica in rhizobial inoculation practices for improving the growth of the common bean. Future field experiments on the co-inoculation of rhizobia with cyanobacteria are needed in order to elucidate the performance of beneficial microorganisms inoculated to the common bean.

\section{Acknowledgements}

EHH and AWSZ acknowledge the scholarships from the National Council for the Improvement of Higher Education (CAPES). This study was partially supported by the National Council for the Improvement of Higher Education (CAPES, 001) and by the INCT-CNPq (Brazilian National Council for Scientific and Technological Development) (MPCPAgro 465133/2014-2). DSA is also a research fellow at CNPq (312996/2017-9).

\section{Reference}

Andrade, D. S., Machineski, G. S., Lovato, G. M., Colozzi, A., Fº, \& Goes, K. C. G. P. de. (2014). Inoculação de microalgas em leguminosas e gramíneas. In D. S., Andrade., \& A. Colozzi, Fº (Eds.), Microalgas de águas continentais: desafios e potencialidades do cultivo (Vol 2, pp. 413-438), Londrina: IAPAR. 
Bashan, Y., Bashan, L. de, Prabhu, S. R., \& Hernandez, J.-P. (2014). Advances in plant growth-promoting bacterial inoculant technology: formulations and practical perspectives (1998-2013). Plant and Soil, 378(1), 1-33. doi: 10.1007/s11104-013-1956-x

Bremner, J., \& Keeney, D. (1965). Steam distillation methods for determination of ammonium, nitrate and nitrite. Analytica Chimica Acta, 32(1), 482-485. doi: 10.1016/S0003-2670(00)88973-4.

Cardoso, J. D., Hungria, M., \& Andrade, D. S. (2012). Polyphasic approach for the characterization of rhizobial symbionts effective in fixing $\mathrm{N}_{2}$ with common bean (Phaseolus vulgaris L.) Applied Microbiology and Biotechnology, 93(5), 2035-2049. doi: $10.1007 / \mathrm{s} 00253-011-3708-2$

Dall'Agnol, R. F., Ribeiro, R. A., Ormeno-Orrillo, E., Rogel, M. A., Delamuta, J. R. M., Andrade, D. S., Martínez-Romero, E., Hungria, M. (2013). Rhizobium freirei sp. nov., a symbiont of Phaseolus vulgaris that is very effective at fixing nitrogen. nternational Journal of Systematic and Evolutionary Microbiology, 63(11), 4167-4173. doi: 10.1099/ ijs.0.052928-0

Egamberdieva, D., Berg, G., Lindström, K., \& Räsänen, L. A. (2010). Co-inoculation of Pseudomonas spp. with Rhizobium improves growth and symbiotic performance of fodder galega (Galega orientalis Lam.). European Journal of Soil Biology, 46(3), 269-272. doi: 10.1016/j.ejsobi.2010.01.005

Ferreira,D.F.(2011). Sisvar: a computer statistical analysis system. Ciência e Agrotecnologia, 35(6), 1039-1042. doi: 10.1590/S1413-70542011000600001

Fukami, J., Cerezini, P., \& Hungria, M. (2018). Azospirillum: benefits that go far beyond biological nitrogen fixation. AMB Express, 8(73), 1-12. doi: 10.1186/s13568-018-0608-1

Fukami, J., Nogueira, M. A, Araujo, R. S., \& Hungria, M. (2016). Accessing inoculation methods of maize and wheat with Azospirillum brasilense. AMB Express, 6(3), 1-13. doi: 10.1186/s13568-015-0171-y

Gange, A. C., \& Gadhave, K. R. (2018). Plant growthpromoting rhizobacteria promote plant size inequality. Scientific Reports, 8(1), 13828. doi: $10.1038 / \mathrm{s} 41598-018-32111-\mathrm{z}$

Ghaderiardakani, F., Collas, E., Damiano, D. K., Tagg, K., \& Graham, N. S. (2019). Effects of green seaweed extract on Arabidopsis early development suggest roles for hormone signalling in plant responses to algal fertilisers. Scientific Reports, 9(1), 1-13. doi: 10.1038/s41598-018-38093-2
Gordillo-Delgado, F., Marín, E., \& Calderón, A. (2016). Effect of Azospirillum brasilense and Burkholderia unamae bacteria on maize photosynthetic activity evaluated using the photoacoustic technique. International Journal of Thermophysics, 37(9), 1-11. doi: 10.1007/s10765-016-2101-X

Hungria, M., Andrade, D. S., Chueire, L. M. D. O., Probanza, A., Guttierrez-Manero, F. J., Megias, M. (2000). Isolation and characterization of new efficient and competitive bean (Phaseolus vulgaris L.) rhizobia from Brazil. Soil Biology \& Biochemistry, 32(11-12), 1515-1528. doi: 10.1016/S0038-0717 (00)00063-8

Hungria, M., Nogueira, M. A., \& Araujo, R. S. (2013). Co-inoculation of soybeans and common beans with rhizobia and azospirilla: strategies to improve sustainability. Biology and Fertility of Soils, 49(7), 791-801. doi: 10.1007/s00374-012-0771-5

Jaiswal, P., Prasanna, R., Nayak, S., Sood, A., \& Suseela, M. (2008). Characterization of rhizo-cyanobacteria and their associations with wheat seedlings. Egyptian Journal of Biology, 10(1), 20-27.

Kazi, N., Deaker, R., Wilson, N., Muhammad, K., \& Trethowan, R. (2016). The response of wheat genotypes to inoculation with Azospirillum brasilense in the field. Field Crops Research, 196(1), 368-378. doi: 10.1016/j.fcr.2016.07.012

Korir, H., Mungai, N. W., Thuita, M., Hamba, Y., \& Masso, C. (2017). Co-inoculation effect of rhizobia and plant growth promoting rhizobacteria on common bean growth in a low phosphorus soil. Frontiers in Plant Science, 8(141), 1-10. doi: 10.3389/fpls.2017.00141

Loreto, C., Rosales, N., Bermúdez, J., \& Morales, E. (2003). Produccion de pigmentos y proteinas de la cianobacteria Anabaena pcc 7120 en relacion a la concentracion de nitrogeno e irradiancia. Gayana Botánica, 60(6), 83-89. doi: 10.4067/S071766432003000200001.

Manjunatha, M., Kanchan, A., Ranjan, K., Venkatachalam, S., Prasanna, R., Ramakrishnan, B., Singh, B. (2016). Beneficial cyanobacteria and eubacteria synergistically enhance bioavailability of soil nutrients and yield of okra. Heliyon, 2(2), 1-28. doi: 10.1016/j.heliyon.2016.e00066

Mulas, D., Seco, V., Casquero, P. A., Velázquez, E., \& González-Andrés, F. (2015). Inoculation with indigenous rhizobium strains increases yields of common bean (Phaseolus vulgaris L.) in northern Spain, although its efficiency is affected by the tillage system. Symbiosis, 67(3), 113-124. doi: 10.1007/ s13199-015-0359-6 
Parra, M. S., \& Oliveira, E. L. (2003). Sugestão de adubação e calagem para culturas de interesse econômico no Estado do Paraná. In: Oliveira, E. L., Feijão (128a ed., pp. 17-18). (Circular Técnica). Londrina: IAPAR.

Peres, A. R., Rodrigues, R. A. F., Arf, O., Portugal, J. R., \& Corsini, D. C. D. C. (2016). Co-inoculation of Rhizobium tropici and Azospirillum brasilense in common beans grown under two irrigation depths. Revista Ceres, 63(2), 198-207. doi: 10.1590/0034737X201663020011

Piotrowska-Niczyporuk, A., Bajguz, A., Kotowska, U., Bralska, M., \& Talarek-Karwel, M. (2018). Growth, metabolite profile, oxidative status, and phytohormone levels in the green alga Acutodesmus obliquus exposed to exogenous auxins and cytokinins. Journal of Plant Growth Regulation, 37(4), 1159-1174. doi: 10.1007/s00344-018-9816-9

Rencher, A. (2002). Methods of multivariate analysis (2nd ed.). New York: A John Wiley \& Sons, Inc. Publication.

Renuka, N., Guldhe, A., Prasanna, R., Singh, P., \& Bux, F. (2018). Microalgae as multi-functional options in modern agriculture: current trends, prospects and challenges. Biotechnology advances, 36(4), 12551273. doi: 10.1016/j.biotechadv.2018.04.004

Rodrigues, A., Antunes, J., Medeiros, V. D. E., Barros, B. D. F., \& Figueiredo, M. D. V. (2012). Co-inoculation response of growth promoting bacterias in plants and Bradyrhizobium sp. in cowpea. Bioscience Journal, 28(1), 196-202.

Schossler, J., Meert, L., Rizzardi, D., \& Michalovicz, L. (2016). Yield components and grain yield of common-bean submitted to the inoculation and coinoculation of Rhizobium tropici and Azospirillum brasilense strains. Revista Scientia Agraria, 17(1), 10-15. doi: 10.5380/rsa.v17i1

Soares, B. L., Ferreira, P. A. A., Rufini, M., Martins, F. A. D., Oliveira, D. P., Reis, R. P., Moreira, F. M. de S. (2016). Agronomic and economic efficiency of common-bean inoculation with rhizobia and mineral nitrogen fertilization. Revista Brasileira de Ciência do Solo, 40(1), 10-15. e0150235. doi: 10.1590/ $18069657 \mathrm{rbcs} 20150235$
Soil Survey Staff(2014). Keys to oil taxonomy (12nd ed.). Washington, DC: Natural Resources Conservation Service. Natural Resources Conservation Service (NRCS), United States Department of Agriculture (USDA).

Stajković, O., Delić, D., Jošić, D., Kuzmanović, Đ., Rasulić, N., \& Knežević-Vukčević, J. (2011). Improvement of common bean growth by coinoculation with Rhizobium and plant growthpromoting bacteria. Romanian Biotechnological Letters, 16(1), 5919-5926.

Steiner, F., Ferreira, H. C. P., \& Zuffo, A. M., (2019). Can co-inoculation of Rhizobium tropici and Azospirillum brasilense increase common bean nodulation and grain yield? Semina: Ciências Agrárias, 40(1), 8198. doi: 10.5433/1679-0359.

Tate, J. J., Gutierrez-Wing, M. T., Rusch, K. A., \& Benton, M. G. (2013). The effects of plant growth substances and mixed cultures on growth and metabolite production of green algae Chlorella $\mathrm{sp}$.: a review Journal of Plant Growth Regulation, 32(2), 417-428. doi: 10.1007/s00344-012-9302-8

Wirtz, N. L., Treble, R. G., \& Weger, H. G. (2010). Siderophore-independent iron uptake by iron-limited cells of the cyanobacterium Anabaena flos-aquae. Journal of Phycology, 46(5), 947-957. doi: 10.1111/ j.1529-8817.2010.00881.x

Yadegari, M. (2014). Evaluation of bean (Phaseolus vulgaris) seeds' inoculation with Rhizobium phaseoli and plant growth promoting rhizobacteria (PGPR) on yield and yield components. Advances in Environmental Biology, 8(2), 419-424.

Yagi, R., Andrade, D. S., Waureck, A., \& Gomes, J. C. (2015). Nodulations and grain yields of common beans in response to nitrogen fertilization or seed inoculation with Rhizobium freirei. Revista Brasileira de Ciência do Solo, 39(6), 1661-1670. doi: 10.1590/0100068rbcs20140342 
